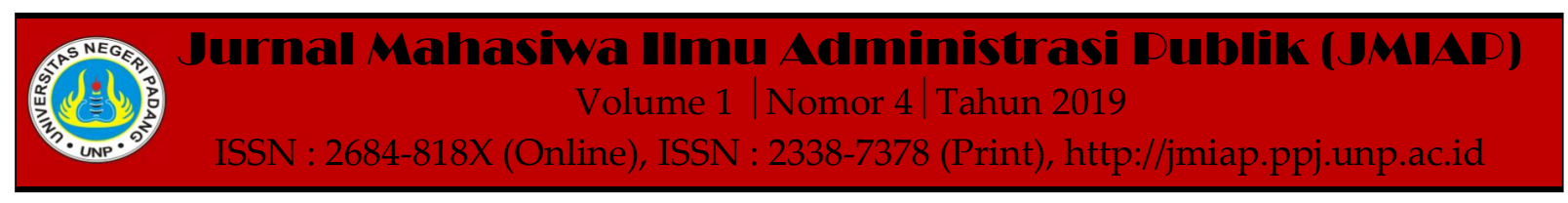

\title{
IMPLEMENTASI PERATURAN DAERAH KOTA BUKITTINGGI NOMOR 2 TAHUN 2015 TENTANG PENCEGAHAN DAN PENANGGULANGAN BAHAYA KEBAKARAN
}

\author{
Yelni Aprina ${ }^{1(a)}$, Rahmadani Yusran ${ }^{2(b)}$ \\ ${ }^{1}$ Jurusan Ilmu Administrasi Negara, Universitas Negeri Padang \\ ${ }^{2}$ Jurusan Ilmu Administrasi Negara, Universitas Negeri Padang \\ a)yelniaprina1@gmail.com, b)yusranrdy@fis.unp.ac.id
}

\begin{abstract}
The purpose of this research was to determine the implementation of the Regional Regulation of Bukittinggi cities Number 2 of 2015 about Fire hazard Prevention and countermeasures. This research is a qualitative research and uses descriptive methods. The research informants were determined using purposive sampling techniques. including the head of the treatise section and the session of the Bukittinggi Cities DPRD, Head of sub-division Documentation and legal counseling of Bukittinggi cities, The head of the prevention section and the head of the operational section of the fire department, Head of K3L PLN of Bukittinggi cities, fire victim and society of Bukittinggi cities. Data collection techniques carried out by observation, interview and study documentation. To test the validity of the data using source triangulation techniques. The results showed that the implementation of local regulations have not been implemented optimally, there are still some aspects that still need attention such as aspects of the target group, aspects of the desired degree of change, resources involved, characteristics of the ruling institutions as well as compliance and responsiveness. There are supporting factors in the implementation of regional regulations such as the socialization carried out by related parties, the implementation of the Regional Regulation is also supported by the provision of training and education to officers so that they have the ability and skills in their fields. Resources and lack of commitment in implementing local regulations. So that efforts are needed by the government in implementing policies.
\end{abstract}

Keywords : Implementation of Policies, Prevention and Mitigation of Fire Hazards, Regional Regulation of Bukittinggi Cities

Corresponding author. Email.yelniaprina1@gmail.com,yusranrdy@fis.unp.ac.id

How to cite this article. Aprina, Y \& Yusran, R. (2019). Implementasi Peraturan Daerah Kota Bukittinggi Nomor 2 Tahun 2015 Tentang Pencegahan dan Penanggulangan Bahaya Kebakaran. Jurnal Mahasiwa Ilmu Administrasi Publik (JMIAP) Jurusan Ilmu Administrasi Negara Fakultas Ilmu Sosial Universitas Negeri Padang, Volume 1 (4), Hal. 87-97.

http://jmiap.ppj.unp.ac.id

ISSN : 2684-818X (Online), ISSN : 2338-7378 (Print)

Copyright $\bigcirc 2019$. Published by Pusat Kajian-Pemberdayaan dan Pelayanan Masyarakat (PK-P2M) FIS UNP Padang 


\section{PENDAHULUAN}

Kebakaran merupakan salah satu bentuk bencana yang memerlukan perhatian khusus dan memerlukan pencegahan dan penanggulangan untuk mengurangi bahkan menghilangkan kemungkinan terjadinya kebakaran, sehingga kebijakan tentang pencegahan dan penanggulangan bahaya kebakaran di kota sangat penting di lakukan. Di Indonesia pencegahan dan penanggulangan bencana ditetapkan dalam UU No 24 Tahun 2007 tentang Penanggulangan Bencana. Selanjutnya kebijakan tentang pencegahan kebakaran ditetapkan dalam Peraturan Menteri Pekerjaan Umum No : 20/PRT/M/2009 tentang pedoman teknis manajemen proteksi kebakaran di perkotaan. Namun demikian bencana kebakaran yang terjadi di berbagai kota di Indonesia masing sering terjadi.

Kota Bukittinggi merupakan kota di Provinsi Sumatera Barat yang termasuk salah satu kota yang memiliki resiko terjadinya bencana kebakaran. Untuk itu dalam upaya mencegah dan menanggulangi bahaya kebakaran, pemerintah Kota Bukittinggi telah menetapkan Peraturan Daerah Nomor 2 Tahun 2015 tentang Pencegahan dan Penanggulangan Bahaya Kebakaran. Perda ini menjelaskan tentang upaya yang dilakukan dalam rangka mencegah terjadinya kebakaran, serta upaya yang dilakukan dalam rangka memadamkan kejadian kebakaran yang ada di kota Bukittinggi. Hal ini, karenakejadian kebakaran di Kota Bukittinggi selama ini masih tinggi, hal ini dapat dilihat dari jumlah kejadian kebakaran sejak tahun 2015 sampai 2018 mengalami fluktuatif, sebagaimana yang terlihat dalam tabel berikut :
Tabel 1.1 Data Jumlah Kejadian

Kebakaran Kota Bukittinggi

\begin{tabular}{llll}
\hline No & Tahun & $\begin{array}{l}\text { Jumlah } \\
\text { Kebakaran }\end{array}$ & Kerugian \\
\hline 1 & 2015 & 112 & $>1$ Milyar \\
\hline 2 & 2016 & 120 & \pm 4.5 Milyar \\
\hline 3 & 2017 & 121 & $>4$ Milyar \\
\hline 4 & 2018 & 77 & $>3$ Milyar \\
\hline
\end{tabular}

Dari data tersebut, terlihat bahwa pada tahun 2015-2017 jumlah kejadian kebakaran mengalami peningkatan, namun pada tahun 2018 jumlah kejadian kebakaran menurun, hal ini menunjukkan angka kejadian kebakaran di kota Bukittinggi masih berfluktuasi.

Kejadian kebakaran dikota Bukittinggi umumnya disebabkan oleh: Pertama rendahnya tingkat kesadaran dan pengetahuan masyarakat diperkotaan tentang meminimalisasi dampak kejadian kebakaran di Kota Bukittinggi. Kedua pencegahan dan penanggulangan kejadian kebakaran di Kota Bukittinggi selama ini belum disertai dengan upaya peningkatan sarana dan prasarana pencegahan kebakaran. Ketiga, Pencegahan dan penanggulangan kejadian kebakaran belum diikuti dengan munculnya kesadaran para pengguna moda transportasi dalam menyediakan Alat Pemadam Api Ringan (APAR) dalam kendaraan. Serta keempat, upaya pencegahan dan penangglangan bahaya kebakaran belum diikuti dengan goodwillPemerintah Kota Bukittinggi dalam menyediakan pos pemadam kebakaran di masing-masing kecamatan, karena sampai saat ini baru terdapat satu pos pemadam kebakaran. Berdasarkan permasalahan inilah penulis merumuskan masalah sebagai berikut: Pertama, Bagaimana implementasi Perda Kota Bukittinggi No. 2 Tahun 2015. Kedua, Apa faktor pendukung dan penghambat dari implementasi Perda kota Bukittinggi No 2 Tahun 2015. Ketiga, Bagaimana upaya pemerintah Kota Bukittinggi dalam implementasi Perda Kota Bukittinggi. 


\section{TINJAUAN PUSTAKA}

\section{Konsep Implementasi Kebijakan}

Implementasi kebijakan merupakan suatu tindakan yang dilakukan setelah suatu kebijakan terapkan sehingga sebuah kebijakan dapat mencapai tujuan. menurut Van meter dan Van Horn dalam (Dedi Mulyadi, 2016) menyatakan bahwa implementasi kebijakan adalah tindakan/kegiatan yang dilakukan oleh pemerintah dan swasta secara individu maupun secara kelompok yang dimaksudkan untuk mencapai sebuah tujuan.

Kemudian, dalam studi implementasi kebijakan, kajian tentang variable atau faktor-faktor determinan keberhasilan implementasi kebijakan ditentukan oleh berbagai faktor (Yusran, 2003:23-25). Misalnya, Garvich (1975) pada mula nya implementasi cenderung mengambil focus pada karakteristik lembaga pelaksana. Meskipun, karakter birokrasi pelaksana berdampak penting terhadap hasil implementasi, tetapi sangat penting untuk mengaitkan karakteristik "isi kebijakan" (content of policy) dan karakteristik "lingkungan" (context of policy) (Grindle, 1983;4-5)dalamYusran (2015). Hal ini, karena pendekatan implementasi yang berfokus pada karakter birokrasi pelaksana cenderung memandang seolah-olah setiap kebijakanakan memiliki problem implementasi yang sama dan mengabaikan bahwa kebijakan yang berbeda akan menghadapi problem implementasi yang berbeda-beda pula.

Berkaitan dengan pendekatan implementasi yang menaruh perhatian terhadap karakterisi kebijakan, kondisi lingkungan dan birokrasi pelaksana (sistemadministrasi), diformulasikan oleh Grindle (1983), Van Meter dan Van Horn (1975), Mazmaniandan Sabatier (1983)dan lain-lain Yusran (2003). Grindle misalnya,melihat implementasi kebijakan sebagai proses administrasi dan sekaligus proses politik dimana hasil implementasiakan ditentukan oleh sejumlah faktor yang dikelompokan kedalam dua variabel, yaitu variable yaitu variabel isi kebijakan (content of policy) dan lingkungan kebijakan (context of policy).

Variabel "content of policy" mencakup faktor-faktor utama berupa; 1) kepentingan yang hendak dicapai; 2) Bentuk keuntungan; 3) tingkat perubahan yang dikehendaki; 4) Ruang pengambilan keputusan; 5) Kondis iimplementor dan dukungan sumber dana. Sedangkanvariabel "context of policy" mencakupfaktor-faktor; 1) Kekuasaan; 2) Kepentingan dan strategi keterlibatan antar aktor; 3) karakter lembaga pelaksana atau pemerintahan; 4) serta Kepatuhan dan daya tanggap lembagapelaksana.

\begin{tabular}{|c|c|}
\hline $\begin{array}{c}\text { Variabel } \\
\text { keberhasilan }\end{array}$ & $\begin{array}{r}\text { mempengaruhi } \\
\text { implementasi }\end{array}$ \\
\hline kebijakanlainnya & kemukakan oleh \\
\hline Jeorge C. Edward & III dalam (D \\
\hline & \\
\hline
\end{tabular}
Komunikasi:komunikasi menjadi pedoman oleh pelaksana/implementator untuk menyampaikan tujuan/sasaran kebijakan yang ingin dicapai dalam implementasi kebiajakan kepada kelompok sasaran, sehingga kelompok sasaran dapat mengetahui dan menjalankan kebijakan tersebut. 2) Sumber daya: sumberdaya dapat terbagi menjadi smber daya manusia dan sumber daya financial, sumber daya manusia artinya implementasi kebijakan harus didukung oleh pelaksana kebijakan yang memiliki kemampuan dan keahlian dibidangnya dalam melaksanakan kebijakan, sementara sumber daya financial merupakan anggaran yang disediakan dalam memenuhi segala kebtuhan yang berhubungan dengan imlementasi kebijakan. 3) Disposisi:Disposisi atau watak pelaksana kebijakan, merupakan karakteristik yang dimiliki oleh implementator dalam menjalankan kebijakan. Seperti komitmen yang dimiliki, sifat kejujuran dan demokratis selama menjalankan kebijakan. 4) Struktur Birokrasi:merupakan suatu hal yang penting karena setiap organisasi atau 
lembaga pemerintahan harus memiliki standar yang jelas (Standard operating procedure atau SOP) dalam menjalankan tugasnya, sehingga SOP menjadi pedoman bagi setiap implemetator dalam melakukan tindakan.

\begin{tabular}{|c|c|}
\hline Konsep & Pencegahan \\
\hline Penanggulanga & Kebakaran \\
\hline Berdasarkan & Peraturan \\
\hline Pekerjaan & Umum \\
\hline
\end{tabular}
26/Prt/M/2008)bahaya kebakaran adalah bahaya yang diakibatkan oleh adanya ancaman potensial dan derajat terkena pancaran api sejak awal kebakaran hingga penjalan api yang menimbulkan asap dan gas. Dapat disimpulkan bahwa kebakaran adalah peristiwa timbulnya api yang tidak terkendali, diluar kemampuan manusia dan berakibat menimbulkan kerugian harta benda, cidera bahkan kematian.

Dalam penelitian yang dilakukan oleh (Putra, 2010) menjelaskan bahwa Pencegahan kebakaran adalah segala daya upaya atau tindakan secara terencana untuk mencegah dan menghilangkan timbulnya kebakaran. Karena itu pencegahan kebakaran dan pemadaman dalam tahap awal penting untuk dilakukan, baik dengan cara meningkatkan ilmu pengetahuan maupun ketrampilan khususnya tentang kebakaran. Sedangkan berdasarkan Peraturan Daerah Kota Bukittinggi Nomor 2 Tahun 2015 Tentang Pencegahan dan Penanggulangan Bahaya Kebakaran, dalam pasal 1 ayat 7 menjelaskan bahwa pencegahan kebakaran adalah upaya yang dilakukan dalam upaya mencegah terjadinya kebakaran. Sedangkan dalam pasal 1 ayat 8 menjelaskan Penanggulangan kebakaran adalah upaya yang dilakukan dalam rangka memadamkan kebakaran.

\section{METODE PENELITIAN}

Penelitian ini merupakan penelitian kualitatif dengan menggunakan metode deskriptif.Tujuannyaadalah

menggambarkan dan menjelaskan fenomena yang diamati secara langsung dan mengasilkan data deskriptif berupa kata- kata tertulis berbentuk naratif.Metode ini diharapkan dapat menjelaskan dan menggambarkan tentang implementasi Peraturan Daerah Nomor 2 Thn 2015 tentang Pencegahan dan Penanggulangan Bahaya Kebakaran. Penelitian ini dilakukan di

Kota

Bukittinggi.Pemilihaninforman,mengguna kan teknik purposive sampling yakni pihakpihak yang memiliki informasi sesuai kebutuhan peneliti, diantaranya kepala bagian risalah dan persidangan DPRD Kota Bukittinggi, Kasubag Dokumentasi dan penyuluhan hukum kota Bukittinggi, Kepala bagian pencegahan serta kepala bagian operasional dinas pemadam kebakaran, Kepala bagian K3L PLN kota Bukittinggi, korban kebakaran serta masyarakat kota Bukittinggi.

Sumber data yang digunakan dalam penelitian ini menggunakan data primer dan data sekunder, yang diambil langsung melalui proses wawancara dan observasi ke lapangan, serta dari sumber bacaan, berita dan perda kota Bukittinggi Nomor 2 Thn 2015. Teknik untuk menguji keabsahan data yang dipakai dalam penelitian ini menggunakan trianggulasi sumber, yakni mengecek data yang diperoleh melalui beberapa sumber. Kemudian dianalisi dengan cara mereduksi data, penyajian data serta menarik kesimpulan.

\section{HASIL DAN PEMBAHASAN}

\section{Implementasi Peraturan Daerah Kota Bukittinggi No. 2 Tahun 2015 Tentang Pencegahan dan Penanggulangan Bahaya Kebakaran}

Mengacu pada model implementasi yang dikemukakan oleh Grindle yang menyatakan bahwa keberhasilan implementasi suatu kebijakan ditentukan oleh dua aspek yaitu isi kebijakan (content of policy) dan lingkungan kebijakan (context of implementation). Isi kebijakan tersebut mencakup hal-hal sebagai berikut : Kepentingan yang terpengaruhi oleh kebijakan, jenis manfaat yang dihasilkan, derajat perubahan yang diinginkan, siapa 
pelaksana program, dan sumber daya yang dikerahkan. Sedangkan lingkungan kebijakan mencakup : Kekuasaan, Kepentingan dan strategi aktor yang terlibat, karekteristik lembaga dan pengusaha serta kepatuhan dan daya tanggap.

\section{a) Aspek Isi Kebijakan}

1) Kepentingan-kepentingan kelompok sasaran

Kepentingan yang mempengaruhi implementasi perda tersebut yakni pertama, kepentingan dari DPRD adalah melakukan pembahasan rancangan Perda yang diajukan Pemerintah Kota (Pemko) bagian hukum dan Dinas Damkar kota Bukittinggi. Selain itu, DPRD Kota Bukittinggi juga melakukan pengawasan terhadap pelaksanaan Perda, pengawasan ini dilakukan dalam bentuk rapat kerja dengan SKPD terkait yang membahas hambatan dan kendala yang ditemui selama pelaksanaan Perda. Berdasarkan temuan di lapangan dapat dikatakan bahwa peran DPRD belum optimal dilakukan, hal ini disebabkan karena pengawasan yang dilakukan oleh DPRD hanya berupa pengawasan melalui rapat kerja, tidak pernah melakukan pengawasan ke masyarakat untuk mengetaahui apakah Perda tersebut telah dijalankan atau belum.

Kedua, kepentingan Pemko Kota Bukittinggi bagian hukum adalah memfasilitasi pembentukan Perda dan Perwako yang berhubungan dengan Perda, Namun kepentingan tersebut belum optimal dilakukan karena pemko tidak pernah melakukan sosialisai secara langsung kepada masyarakat, tentang Perda No. 2 Thn 2015 tersebut, padahal sosialisasi seharusnya dilakukan sekali setahun, pihak pemko hanya memasukkan Perda ke dalam Website kota Bukittinggi.

Ketiga, kepentingan Dinas Damkar adalah selain sebagai inisiator dalam mengajukan rancangan tertulis tentang Perda No. 2 Thn 2015, Pihak Damkar juga sebagai pelaksana atau penanggungjawab utama untuk menentukan keberhasilan dalam meningkatkan pemahaman tentang upaya pencegahan dan penanggulangan bahaya kebakaran.

Dari pembahasan diatas dapat disimpulkana bahwa aspek kepentingan yang terpengaruhi oleh kelompok sasaran dapat dikatakan belum optimal. karena dalam pelaksanaan Perda No. 2 Thn 2015 kepentingan Dinas Damkar telah dijalankan dengan baik, sementara kepentingan dari pihak DPRD dan Pemko bagian hukum belum optimal dilakukan.

2) Tipe manfaat

Manfaat yang dihasilkan dalam implementasi Perda adalah dapat mendoron gtingkat partisipasi masyarakat dalam menanggulangi bahaya kebakaran di wilayahnya. Peningkatan partisipasi masyarakat ini, juga dapat membantu keterbatasan petugas pemadam kebakaran dalam menanggulangi bahaya kebakaran. Selain itu, peningkatan partisipasi masyarakat juga dapat membantu mengoptimalkan tugas pemadam kebakaran yang jumlah sumberdayanya terbatas. serta manfaat yang diperoleh dalam pelaksanaan perda adalah mengoptimalkan peran petugas Damkar dalam memberikan pengetahuan dini tentang pencegahan kebakaran kepada masyarakat. Aspek jenis manfaat ini telah terlaksana baik bagi masyarakat maupun Dinas Damkar, hal ini dapat dilihat dari tingkat partisipasi masyarakat jika terjadi kebakaran di wilayahnya yang cukup tinggi, serta berbagai kegiatan sosialisai yang diberikan oleh damkar kepada masyarakat untuk memberikan pengetahuan dini tentang upaya pencegahan dan penangguulangan bahaya kebakaran.

3) Derajatperubahan yang diinginkan

Perubahan yang diinginkan dari implementasi Perda No 2 thn 2015 tentang Pencegahan dan Penangggulangan Bahaya Kebakaran adalah meningkatnya tingkat kesadaran masyarakat dalam upaya 
pencegahan kebakaran, perubahan yang diinginkan lainnya adalah menurunnya jumlah peristiwa kejadian kebakaran di Kota Bukittinggi.

Sesuai dengan yang diungkapkan Grindle (dalam Haedar 2008) bahwa, derajat perubahan memiliki target yang hendak dan ingin dicapai dengan adanya kebijakan tersebut. Namun demikian implementasi Perda No. 2 Thn 2015 belum optimal dilakukan. Hal ini, terlihat dari angka kejadian kebakaran di Kota Bukittinggi masih berfluktuasi.

4) Pelaksana program

Sesuai dengan Pasal 5 Perda No. 2 Thn 2015 bahwa badan / instansi terkait adalah satuan kerja perangkat daerah kota Bukittinggi yang berwenang dan bertanggungjawab dalam penanggulangan bencana kebakaran. Berdasarkan temuan dilapangan, pelaksana Perda No. 2 tahun 2015 adalah pihak Dinas pemadam kebakaran Kota Bukittinggi yang telah dilatih dan memiliki kemampuan dibidangnya dalam upaya pencegahan dan penanggulangan bahaya kebakaran. Misalnya, Dinas damkar pada bidang pencegahan yang bertugas melakukan pencegahan, sosialisasi, penyuluhan dan kegiatan-kegiatan dalam upaya pencegahan kebakaran, sedangkan bidang pengendalian operasional dan penanganan kebakaran bertugas untuk memadamkan api jika terjadi kejadian kebakaran.

Sebagaimana pendapat Grindle (dalam Haedar 2008) menyatakan bahwa dalam melaksanakan suatu kebijakan harus didukung dengan adanya pelaksana yang memiliki kompetensi dan kualitas yang baik. Aspek ini telah dilaksanakan oleh petugas Damkar, hal ini terlihat dari pelatihan yang diterima oleh petugas Damkar dalam meningkatkan kemampuan dan pengetahuan dalam upaya pencegahan dan penanggulangan bahaya kebakaran.
5) Sumberdaya yang dilibatkan

Sumber daya yang dilibatkan dalam implementasi perda No. 2 Tahun 2015 tentang Pencegahan dan Penanggulangan Bahaya Kebakaran yakni Sumber daya manusia atau personil, serta kelengkapan sarana dan prasarana yang dimiliki oleh pihak Dinas damkar dalam melakukan pencegahan dan penanggulangan bahaya kebakaran di kota Bukittinggi. Berdasarkan teman dilapangan bahwa sumberdaya manusia atau petugas pemadam kebakaran yang dimiliki oleh Dinas Damkar masih terbatas, akan tetapi kelengkapan sarana dan prasarana sudah cukup lengkap.

Sumber daya yang dilibatkan menjadi tolak ukur keberhasilan suatu implementasi menurut Grindle ( dalam Haedar 2008) karena dengan sumber daya yang berkualitas, implementasi akan berjalan dengan baik. Hal ini juga sesuai dengan pendapat Edward III dalam Dedi Mulyadi (2015:68) bahwa apabila implementator kekurangan sumber daya ntuk melaksanakan, implemenetasi tidak akan berjalan efektif, sumber daya tersebut dapat berbentuk sumber daya manusia, dan sumber daya finansial. Berdasarkan pernyataan tersebut dalam aspek sumber daya belum terlaksana dengan optimal, hal ini disebabkan karena dalam pelaksanaan implementasi Dinas Damkar masih kekurangan sumber daya manusia serta keterbatasan sumber daya financial atau anggaran yang ada.

\section{b) Aspek Lingkungan}

1) Seberapa besar kekuasaan, kepentigan dan strategi yang dimiliki oleh para aktor yang terlibat dalm implementasi kebijakan.

Strategi yang dilakukan oleh pihak damkar dalam implementasi Perda No. 2 Tahun 2015 adalah, Pertama melakukan pengawasan terhadap proteksi kebakaran untuk bangunan gedung. Biasanya pengawasan ini dilakukan terhadap bangunan gedung perkantoran, hotel, rumah 
makan, SPBU dan tempat usaha lainnya, bangunan rumah sakit dan lainnya, proteksi kebakran yang dimaksud berupa alat pemadam api ringan (APAR), APAM dan APAB serta sarana penyelamatan jiwa lainnya.

Kedua, melakukan sosialisasi dengan publikasi dan informasi kepada masyarakat, publikasi yang dilakukan berupa sosialisasi menggunakan spanduk, himbauanhimbauan kepada masyarakat, baliho, salebaran, stiker dan lainnya dalam upaya pencegahan kebakaran. Ketiga pihak PLN sebagai instansi yang ikut terlibat dalam upaya pencegahan kebakaran juga melakukan sosialisasi dan pengawasan tentang pemakaian listrik.

Berdasarkan hal tersebut bahwa pada aspek strategi yang dimiliki oleh para aktor dalam implementasi Perda No. 2 Tahun 2015 telah optimal dilakukan. Hal ini dapat dilihat dari pengawasan dan sosialisasi yang dilakukan oleh pihak Damkar beserta PLN dalan pelaksanaan kebijakan.

2) Karakteristik Lembaga penguasa

Berdasarkan Perda No. 2 Tahun 2015 pasal 33 menyatakan bahwa dalam upaya menanggulangi kebakaran dan bencana lainnya dikecamatan dibentuk pos pemadam kebakaran kecamatan, dan di Kelurahan dibentuk kelompok relawan/ Balakar kelurahan yaitu Ketahanan Bencana Lingkungan Kelurahan (KBLK). Berdasarkan temuan di lapangan Dinas Damkar Kota Bukittinggi telah memiliki satu pos pembantu yang berada di kecamatan mandiangin koto selayan, pos ini fungsinya mempercepat respon damkar dalam melakukan pencegahan dan penanggulangan bahaya kebakaran di Kota Bukittinggi, jika terjadi kejadian kebakaran di kecamatan tersebut, maka Dinas damkar akan berkoordinasi dengan pos pembantu tersebut untuk melakukan tindakan awal.

Grindle dalam Haedar (2008) mengungkapkan karakteristik lembaga penguasa yakni bagaimana keberadaan lembaga dimana lingkungan tempat kebijakan tersebut diimplementasikan. Sesuai dengan pendapat grindle pada aspek karakteristik lembaga penguasa ini belum terlaksana dengan optimal, hal ini terlihat dari 3 kecamatan yang ada di Kota Bukittinggi baru terdapat 1 pos pembantu/ sektor yang didirikan, hal ini mengakibatkan kecamatan lain mendapat respon yang kurang cepat dibandingkan dengan kecamatan yang terdapat pos pemadam kebakaran.

3) Tingkat kepatuhan dan adanya respon dari pelaksana

Tingkat kepatuhan dalam implementasi Perda No. 2 Tahun 2015 menunjukkan komitmen kelompok sasaran masih rendah dalam menyediakan peralatan/ sarana dan prasarana pencegahan kebakaran. Akibatnya jika terjadi kejadian kebakaran respon dalam mencegah bahaya kebakaran menjadi lambat.

Selanjutnya terkait respon atau daya tanggap yang diberikan pelaksana kebijakan, bahwa respon yang diberikan oleh pihak Dinas Damkar jika terjadi kejadian kebakaran sudah optimal, hal ini terlihat dari respon dari pemadam kebakaran jika terjadi kejadian kebakaran sudah cukup cepat dilakukan, sesuai dengan pendapat Edward III dalam Haedar (2008) bahwa sikap pelaksana merupakan faktor penting dalam implementasi kebijakan, implementator tidak hanya harus mengetahui apa yang harus dilakukan dan memiliki kapasitas untuk melaksanakannya, tetapi juga harus memiliki keinginan untuk melaksanakan kebijakan tersebut.

Faktor pendukung dan penghambat implementasi Perda No. 2 Tahun 2015 Tentang Pencegahan dan Penanggulangan Bahaya Kebakaran.

Faktor pendukung dan penghambat keberhasilan implementasi Perda No. 2 Tahun 2015 yang mengacu pada teori yang dikemukakan oleh George C. Edward III dalam Dedi Mulyadi (2015:68) bahwa, 
terdapat empat faktor yang mempengaruhi implementasi kebijakan yakni Komunikasi, sumber daya, disposisi dan struktur birokasi, yang mana keempat faktor tersebut dapat dijelaskan sebagai berikut:

\section{1) Faktor pendukung}

a) Komunikasi

Faktor pendukung dari implementasi Perda No. 2 Tahun 2015 pada aspek komunikasi berdasarkan temuan dilapangan bahwa yang dilakukan oleh pelaksana kebijakan/ dinas pemadam kebakaran berupa sosialisasi dan penyuluhan kepada masyarakat, baik itu penyuluhan yang diberikan ke kelurahan setempat, maupun sosialisasi yang dilakukan ke sekolahsekolah maupun tempat-tempat umum, bentuk sosialisasi pun ada yang secara langsung dan melalui media-media berupa spanduk, baliho, rollbanner, himbauanhimbauan dijalan, stiker dan lain sebagainya.Dengan adanya sosialisasi dan media-media publikasi yang telah dilakukan oleh Dinas Damkar tersebut membuat sasaran dan tujuan dari kebijakan dapat tersampaikan.

b) Sumber Daya

Dalam implementasi Perda No. 2 Tahun 2015 faktor pendukung dalam pelaksanaan Perda yakni adanya pelatihan yang dilaksanakan dinas damkar kepada seluruh karyawan untuk meningkatkan kompetensi dan skill di bidangnya, terkhusus bidang pencegahan dan penanggulangan bencana, pelatihan tersebut dilakukan sekali setahun termasuk latihan gabungan dengan dinas damkar dari kota dan kabupaten lainnya. Faktor pendukung lainnya yakni kelengkapan sarana dan prasarana yang dimiliki oleh Dinas damkar dalam upaya penanggulangan jika terjadi kebakaran.

\section{c) Disposisi}

Pada aspek disposisi dalam implementasi Perda No. 2 Tahun 2015, bahwa sikap pelaksana terhadap upaya pencegahan dan penanggulangan kebakaran cukup baik. Pihak damkar selalu berusaha untuk melakukan sosialisasi secara aktif pada berbagai kalangan masyarakat. Dengan sosialisasi ini dapat menambah tingkat pemahaman masyarakat dalam mencegah kejadian kebakaran. Serta petugas Damkar memberikan respon yang cepat dalam menanggapi apabila terjadi kejadian kebakaran, misalnya ada masyarakat yang memberitahukan terjadinya kebakaran, petugas Damkar segera mendatangi lokasi.

d) Struktur Birokrasi

Salah satu dari aspek struktur yang penting menurut Edward C.III dari setiap organisasi adalah adanya prosedur operasi yang standar (Standard operating procedure atau SOP). SOP menjadi pedoman bagi setiap implemetator dalam bertindak. faktor pendukung pada aspek ini bahwa Perda No. 2 Tahun 2015 merupakan SOP atau acuan oleh petugas damkar dalam melaksanakan kegiatan yang berhubungan dengan pencegahan dan penanggulangan bahaya kebakaran.. berdasarkan pasal-pasal yang terdapat di dalam Perda No. 2 Tahun 2015 itu menjadi pedoman bagi dinas damkar dalam menetapkan standar pencegahan dan penanggulangan kebakaran sesuai dengan yang telah ditetapkan. selain itu, PLN kota Bukittinggi sebagai instansi yang ikut melakukan pengawasan juga menetapkan standar dalam pemasangan instalasi listrik yang benar, hal ini dilakukan dalam upaya pencegahan kebakaran.

\section{2) Faktor penghambat}

a) Komunikasi

Faktor penghambat dalam implementasi Perda No. 2 Tahun 2015 adalah masih kurangnya sosialisasi yang diberikan oleh pihak Damkar kepada masyarakat, sosialisasi yang diberikan juga tidak merata, ada masyarakat yang pernah dapat sosialisasi ada yang belum pernah sama sekali mendapat sosialisasi dari dinas pemadam kebakaran, hal ini membuat masyarakat tidak menjalankan apa yang seharusnya ditetapkan didalam perda tersebut. Selain itu faktor kurangnya minat baca masyarakat terhadap spanduk- 
spanduk, baliho maupun brosur-brosur yang disebar menjadi salah satu faktor penghambat dalam implementasi Perda No.

2 Tahun 2015 tentang pencegahan dan penanggulangan bahaya kebakaran. Dapat disimpulkan bahwa komunikasi yang dilakukan oleh pihak Damkar belum maksimal dilakukan.

b) Sumber Daya

Dalam pelaksanaan Perda No. 2 Tahun 2015 yang menjadi faktor penghambat yakni terbatas nya sumber daya manusia yang ada di dinas damkar, personil pemadam kebakaran berjumlah 13 orang, bertugas di sektor pembantu 4 orang, padahal seharusnya dalam satu regu berjumlah 6 orang, jadi di sektor pembantu masih kekurangan personil pemadam kebakaran. selain itu dalam sumber daya financial juga memiliki keterbatasan anggaran, sehingga sosialisasi yang seharusnya dilaksanakan, menjadi terkendala akibat terbatasnya dana, sehingga implementasi Perda No. 2 Tahun 2015 tentang pencegahan dan penanggulangan bahaya kebakaran belum terlaksana dengan optimal. sebagaimana ungkapan Edward C. III dalam Dedy Mulyadi (2015) yakni apabila implementator kekurangan sumber daya untuk melaksanakan kebijakan, implementasi tidak akan berjalan efektif.

c) Disposisi

Implementasi Perda terkendala komitmen yang kurang tegas dalam melaksanakan kebijakan, sehingga kelompok sasaran yang seharusnya mematuhi aturan yang telah ditetapkan tidak melaksanakan aturan karena tidak dijalankannya saksi sebagaimana yang terdapat di dalam perda, pihak Damkar hanya memberikan teguran dan masukan terhadap bangunan yang tidak melengkapi persyaratan bangunan gedung membuat aturan yang terdapat di dalam perda tidak terimplementasikan dengan optimal. Hal ini sesuai dengan yang dikemukakan oleh Edward C. III dalam Dedy Mulyadi (2015) bahwa sikap pelaksana dalam implementasi kebijakan mempengaruhi keberhasilan kebijakan.

\section{d) Struktur Birokrasi}

Menurut Edward C. III menyatakan bahwa aspek struktur yang penting dari setiap organisasi adalah adanya prosedur organisasi yang standar, namun dalam mengimplementasikan kebijakan tersebut standar tersebut sering diabaikan oleh masyarakat, sehingga hal ini menjadi salah satu faktor penghambat dalam implementasi Perda No. 2 Tahun 2015 tentang pencegahan dan penanggulangan bahaya kebakaran.

\section{Upaya yang dilakukan untuk mengatasi kendala dalam implementasi Perda Kota Bukittinggi no 2 tahun 2015}

Agar implementasi Peraturan Daerah Kota Bukittinggi No. 2 Tahun 2015 dapat berjalan dengan optimal, Dinas damkar melakukan evaluasi dalam implementasi kebijakan ini, sehingga dilakukan beberapa upaya dalam mengatasi beberapa kendala yang timbul dalam pelaksanaan Perda No. 2 Tahun 2015, upaya tersebut dapat dilihat melalui aspek yang dikemukakan oleh George Edward C. III yaitu komunikasi, sumber daya, disposisi, serta struktur birokrasi, sebagaimana dijelaskan sebagai berikut :

\section{1) Komunikasi}

Upaya yang dilakukan oleh Dinas damkar dalam meningkatkan komunikasi adalah membentuk Balakar atau barisan relawan kebakaran sebagai perpanjangan tangan dari Dinas pemadam kebakaran dan merupakan media komunikasi Dinas Damkar dengan masyarakat, Balakar akan mencarikan akses jalan terdekat dengan lokasi kejadian kebakaran jika terjadi kebakaran, serta balakar juga mengingatkan masyarakat untuk selalu waspada dan hatihati terhadap penyebab terjadinya kebakaran. Upaya yang dilakukan tersebut belum efektif dilaksanakan karena belum semua kelurahan telah dibentuk Balakar, sehingga komunikasi yang dilakukan oleh 
pihak Damkar dengan masyarakat masih belum optimal dilakukan, hal ini sesuai dengan pendapat Edward C.III dalam Dedy Mulyadi (2015) bahwa apa yang menjadi tujuan dan sasaran kebijakan harus disampaikan secara jelas kepada kelompok sasaran.

2) Sumber Daya

Upaya yang dilakukan dalam implementasi Perda No. 2 Tahun 2015, untuk mengatasi keterbatasan sumber daya manusia dilakukan dengan memberikan pelatihan rutin kepada personil maupun kepada balakar yang ada di kelurahan, hal ini dimaksudkan untuk meningkatkan kemampuan petugas pemadam kebakaran dan balakar. selain itu untuk mengatasi keterbatasan anggaran pihak Damkar berupaya memaksimalkan anggaran yang ada dengan melakukan sosialisasi berdasarkan inisiatif dari masyarakat, serta keterbatasan anggaran tersebut akan disampaikan dalam rapat kerja yang diadakan oleh DPRD untuk dibahas dan dicarikan solusinya, sehingga implementasi Perda No. 2 Tahun 2015 dapat dilaksanakan dengan optimal.

\section{3) Disposisi}

Upaya yang dilakukan oleh Dinas Damkar dalam melaksanakan Perda No. 2 Tahun 2015 adalah dengan menegur pemilik dan pengguna bangunan yang tidak memenuhi standar, serta memberikan saran bagaimana seharusnya sarana / proteksi kebakaran yang harus dilengkapi oleh pemilik, pengguna/ pengelola bangunan tersebut. Selain itu untuk memberikan respon yang cepat kepada masyarakat, Dinas Damkar Kota Bukittinggi telah memiliki satu pos sektor yang berlokasi di kecamatan Mandiangin Koto Selayan, hal ini menjadikan respon yang diberikan oleh petugas Damkar menjadi lebih cepat.

Sebagaimana pendapat Edward C. III dalam Dedy Mulyadi (2015) bahwa disposisi adalah watak dan karakter yang dimiliki oleh implementator, seperti komitmen, kejujuran dan sifat demokratis, apabila implementator memiliki disposisi yang baik seperti apa yang diinginkan oleh pembuat kebijakan, maka proses implementasi kebijakan dapat berjalan efektif, namun kurangnya komitmen yang dimiliki oleh petugas Damkar dalam pelaksanakan kebijakan, menyebabkan implementasi kebijakan belum berjalan efektif sebagaimana yang ditetapkan.

\section{4) StrukturBirokrasi}

Salah satu upaya yang dilakukan oleh pihak damkar dalam implementasi Perda No. 2 Tahun 2015 yakni menjadikan Perda No. 2 Tahun 2015 sebagai pedoman dalam menjalankan kebijakan pencegahan dan penanggulangan bahaya kebakaran, karena standar-standar yang seharusnya dilengkapi oleh pemilik, pengguna maupun pengelola bangunan, perumahan maupun kendaraan telah tertulis di dalam Perda tersebut, Dinas damkar melakukan pengawasan terkait dengan standar yang telah ditentukan tersebut agar pelaksanaan Perda No. 2 Tahun 2015 dapat berjalan dengan baik. Selain itu pihak PLN juga ikut mensosialisasikan pencegahan kebakaran dengan himbauan-himbauan masalah listrik sehingga masyarakat dapat memasang dan menggunakan listrik sesuai dengan standar yang ada. Hal ini sesuai dengan pendapat Edward C. III dalam Dedi Mulyadi (2015) bahwa salah satu dari aspek struktur yang penting dari setiap organisasi adalah adanya prosedur operasi yang standar, SOP menjadi pedoman bagi setiap implementator dalam bertindak.

\section{PENUTUP}

Berdasarkan hasil penelitian dan pembahasan yang dilakukan, maka dapat ditarik kesimpulan bahwa :

1. Proses implementasi Perda Kota Bukittinggi No. 2 Tahun 2015 tentang Pencegahan dan Penanggulangan Bahaya Kebakaran yang mengacu pada model implementasi yang dikemukakan oleh Merilee S. Grindle belum terimplementasikan dengan optimal, masih terdapat beberapa aspek yang 
masih kurang terimplementasikan seperti kepentingan kelompok sasaran, aspek derajat perubahan yang diinginkan, Sumber Daya yang dilibatkan, Karakteristik lembaga penguasa serta kepatuhan dan daya tanggap.

2. Faktor pendukung dari Implementasi Perda Kota Bukittinggi No. 2 Tahun 2015 adalah adanya sosialisasi yang diberikan oleh pihak Damkar baik secara langsung maupun melaui media publikasi seperti spanduk, baliho, brisur dan sebagainya. Kemudian pada aspek sumber daya, pelaksanaan Perda di dukung oleh pemberian pelatihan dan pendidikan kepada petugas damkar dalam meningkatkan kompetensi, serta sarana dan prasarana yang dimiliki oleh Dinas damkar dalam penanggulangan bencana kebakaran sudah cukup lengkap. Selain itu disposisi yang dimiliki oleh pelaksana kebijakan sudah cukup baik. Sedangkan faktor penghambat dari implementasi Perda No. 2 Tahun 2015 adalah tidak meratanya sosialisasi yang diberikan, terbatasnya anggaran dana yang disediakan dalam upaya pencegahan kebakaran, terbatasnya personil pemadam kebakaran serta masih kurangnya komitmen dalam pelaksanaan Perda.

3. Upaya yang dilakukan oleh pihak Dinas Damkar dalam implementasi Perda Kota Bukittinggi No. 2 Tahun 2015 adalah membentuk Balakar (Barisan relawan kebakaran) sebagai perpanjangan tangan dinas pemadam kebakaran sebgai media komunikasi antara Dinas Damkar dengan masyarakat, Kemudian utuk mengatasi keterbatasan dana, dinas Damkar berusaha memaksimalkan anggaran yang ada dan menyampaikan permasalahan yang ditemui selama implementasi Perda No. 2 Tahun 2015 kepada DPRD melalui rapat kerja dengan instansi dan SKPD terkait untuk dibahas dan dicarikan solusi.

\section{DAFTAR KEPUSTAKAAN}

Dedi Mulyadi. (2016). Studi Kebijakan Publik Dan Pelayanan Publik (Konsep Dan Aplikasi Proses Kebijakan Publik Dan Pelayanan Publik Berbasis Analisis Bukti Untuk Pelayanan Publik). Bandung: Alfabeta.

Putra, Bramastya. Kharisma. (2010). Pencegahan Dan Penanggulangan Kebakaran Di Pt.Inka (Persero) Madiun Jawa Timur Universitas Sebelas Maret. Surakarta.

Yusran, $\quad 2003$. ProblematikaKebijakanPembentukkan ProvinsiKepulauan Riau. Tesis, Program Pascasarjana Universitas Gadjah Mada. Yogyakarta. (https://repository.ugm.ac.id/62150/).

Peraturan Daerah Kota Bukittinggi Nomor 2 Tahun 2015 Tentang Pencegahan dan Penanggulangan Bahaya Kebakaran.

Peraturan Menteri Pekerjaan Umum Nomor: 26/Prt/M/2008 Tanggal 30 Desember 2008 Tentang Persyaratan Teknis Sistem Proteksi Kebakaran Pada Bangunan Gedung Dan Lingkungan. 